\title{
Male breast cancer, age and sex chromosome aneuploidy
}

\author{
P A Jacobs ${ }^{1,2}$, V Maloney ${ }^{1}$, R Cooke ${ }^{3}$, J A Crolla ${ }^{1,2}$, A Ashworth ${ }^{4,5,6}$ and A J Swerdlow ${ }^{\star, 3,4}$ \\ ${ }^{1}$ Wessex Regional Genetics Laboratory, Salisbury Foundation NHS Trust, Salisbury SP2 8BJ, UK; ${ }^{2}$ Division of Human Genetics, \\ University of Southampton Medical School, Southampton SO16 6YD, UK; ${ }^{3}$ Division of Genetics and Epidemiology, Institute of \\ Cancer Research, Sutton, Surrey SM2 5NG, UK; ${ }^{4}$ Division of Breast Cancer Research, Institute of Cancer Research, London SW7 \\ 3RP, UK; ${ }^{5}$ Breakthrough Breast Cancer Research Centre, Institute of Cancer Research, London SW3 6JB, UK; ${ }^{6}$ Division of Molecular \\ Pathology, Institute of Cancer Research, London SW7 3RP, UK
}

Background: In cultured, dividing transformed T lymphocytes and in dividing bone marrow cells from normal men and those with a haematological malignancy, sex chromosome aneuploidy has been found to increase in prevalence and degree with age. This has rarely been investigated in non-dividing uncultured blood samples. The loss and gain of the $X$ chromosome in dividing transformed lymphocytes in women with age is much more frequent than that of the $Y$ chromosome in males. However, paradoxically $X$ chromosome aneuploidy is rarely seen in the dividing cells of bone marrow of females.

Methods: In blood samples from 565 men with breast cancer and 54 control men from the England and Wales general population, 80 cell nuclei per sample were scored for presence of $X$ and $Y$ chromosomes using fluorescent centromeric probes.

Results: Sex chromosome aneuploidy, largely Y chromosome loss, was present in $63 \%$ of cases and $57 \%$ of controls, with the prevalence and degree of aneuploidy increasingly sharply and highly significantly with age. At ages $65-80$ years, $71 \%$ of cases and $85 \%$ of controls showed aneuploidy and $15 \%$ and $25 \%$, respectively, had $\geqslant 10 \%$ of cells aneuploid. Allowing for age, aneuploidy was less prevalent $(P=0.03)$ in cases than controls.

Conclusion: Sex chromosome aneuploidy in non-dividing nuclei of peripheral blood cells is frequent in adult men, the prevalence and degree increasing sharply with age. The possible relation of sex chromosome aneuploidy to breast cancer risk in men, and to cancer risk generally, needs further investigation, ideally in cohort studies.

In 1961 it was shown that human chromosome counts, obtained by examining peripheral blood stimulated to divide in culture by phytohaemagglutin, showed an ageing effect that was present both in individuals with a normal chromosome constitution and in individuals with Down and Klinefelter Syndromes (Jacobs et al, 1961). In all three populations the proportion of cells with a missing or additional chromosome (i.e. aneuploid cells) increased approximately in proportion to the age of the individual. A similar study of patients with a variety of cancers showed no difference between the cancer patients overall and normal individuals (Buckton et al, 1962). It was later postulated that the missing or additional chromosome responsible for this effect was the $\mathrm{Y}$ chromosome in men and the $\mathrm{X}$ chromosome in women (Jacobs et al, 1963). This was subsequently confirmed using banding techniques (Galloway and Buckton, 1978). In virtually all studies aneuploidy of the $\mathrm{X}$ chromosomes in females was very much more frequent than that of the $\mathrm{Y}$ chromosome in males.

Transformed cells in blood cultures consist of T lymphocytes; thus, the majority of data on the loss or gain of sex chromosomes with age refer only to $\mathrm{T}$ cells. However, studies of direct preparations of bone marrow cells from men with a haematological malignancy showed a relatively large proportion to have a cell line with a 45, $\mathrm{X}$ constitution, the $\mathrm{Y}$ chromosome being absent (O’Riordan et al, 1970). Chromosome studies of bone marrow from men who did not have haematological disease were also found 
to have $45, \mathrm{X}$ cells, in a similar proportion to that in patients with haematological malignancy (O'Riordan et al, 1970; United Kingdom Cancer Cytogenetics Group (UKCCG), 1992). There are very few published data on sex chromosome aneuploidy in the marrow cells of females with or without a haematological malignancy, but it appears that $\mathrm{X}$ chromosome aneuploidy is not a feature of the marrow cells of ageing women (Secker Walker 1971).

There are a very few studies of sex chromosome aneuploidy in which non-dividing nuclei, either cultured or uncultured, have been observed using in-situ hybridisation with chromosomespecific probes (Cremer et al, 1986; Eastmond and Pinkel 1990) and only two of which we are aware, where investigators have used $\mathrm{X}$ - and Y-specific probes to investigate age-related sex chromosome aneuploidy (Guttenbach et al, 1994; 1995). Furthermore, since the early reports, which are restricted to relatively small numbers, little has been reported on Y chromosome aneuploidy in ageing males.

While we were using $\mathrm{X}$ and $\mathrm{Y}$ centromere probes on blood films from a population of adult men with breast cancer in order to detect those with a constitutional sex chromosome abnormality, we took the opportunity to study the effect of age on sex chromosome aneuploidy. As only 35 of the 138 males studied by Guttenbach et al (1995) were $>60$ years of age, we thought that our study involving 565 men of whom 330 were $\geqslant 65$ years would be a useful addition to the information on sex chromosome aneuploidy in ageing males.

\section{MATERIALS AND METHODS}

We undertook a population-based case-control study in England and Wales of the genetic, environmental and behavioural causes of breast cancer in men. All men resident in these countries with breast cancer diagnosed at ages 18-79 since 1 January 2005 were potentially eligible to be cases, and interviews were conducted with as many of these subjects as possible.

The controls for the study, who were in the same age range and did not have breast cancer, were identified from two sources in England and Wales. The first was male non-blood relatives of the cases, and the second was husbands of women without breast cancer taking part in the Breakthrough Generations Study (BGS), a large national cohort study of women in the general population of the UK (Swerdlow et al, 2011). The study was approved by the South East Multicentre Research Ethics Committee.
Because breast cancer is more frequent in males with a 47,XXY chromosome constitution (Klinefelter syndrome) than in 46,XY males (Swerdlow et al, 2005), we obtained blood samples to test for the presence of a constitutional 47,XXY cell line. The blood samples from cases and controls were coded and sent to the laboratory, where they were scored blind. To test the sex chromosome status, dried blood smears were fixed in four changes of $3: 1$ methanol:acetic acid, air-dried and aged under UV light for $20 \mathrm{~s}$. Probe mix containing centromere probes for the $\mathrm{X}$ and $\mathrm{Y}$ chromosomes, respectively, was hybridised for $2 \mathrm{~h}$ and following a stringent wash the slides were counterstained and examined under a fluorescence microscope. Wherever possible 80 cell nuclei from blood samples were scored for the presence of the $\mathrm{X}$ and $\mathrm{Y}$ chromosomes. Preparations with fewer than 30 cells scored proved to be of insufficient quality to score the sex chromosome constitution accurately and therefore are excluded from this paper. Similarly, buccal swabs, which we took where phlebotomy was not possible, proved to be of insufficient quality for accurate scoring and are not included.

\section{RESULTS}

Eight hundred and thirty nine men with breast cancer were interviewed at ages $\leqslant 80$ years (generally a year or two after diagnosis), of whom 637 (76\%) donated a blood sample for cytogenetic testing. Seventy two of these were not included in the results presented here because their constitution was XXY or XX (transgender individuals or female bone marrow transplant) (7), testing failed (1), or too few cells were scored (64). Thus, 565 samples from breast cancer patients are included in the present analyses. Thirty four (6\%) of the cases had their samples taken $<6$ months after cancer diagnosis, 388 (69\%) at 6-23 months after diagnosis and $143(25 \%) \geqslant 2$ years after diagnosis. Three hundred and thirty (58\%) cases were aged $65-80$ years and $42 \%$ younger. Samples from 54 controls aged 29-78 (39 non-blood relatives of cases, 15 husbands of BGS members), were tested as the comparison group. Twenty (37\%) of the controls were aged 6580 and $63 \%$ younger (they were selected stratified by age in order to give sufficient controls at each age group).

Table 1 shows the proportion of cells with sex chromosome aneuploidy, that is, that did not have an XY sex chromosome constitution, in cases and controls. Overall, 63\% of cases and 57\% of controls showed aneuploidy. Both cases and controls showed a significant increase in sex chromosome aneuploidy with age

Table 1. Degree of sex chromosome aneuploidy in white blood cells from male breast cancer cases and general population controls, by age

\begin{tabular}{|c|c|c|c|c|c|c|c|c|}
\hline \multirow[b]{3}{*}{$\begin{array}{l}\text { Proportion of aneuploid } \\
\text { cells }(\%)\end{array}$} & \multicolumn{8}{|c|}{ Age at cytogenetic testing (years) } \\
\hline & \multicolumn{2}{|c|}{$<45$} & \multicolumn{2}{|c|}{$45-64$} & \multicolumn{2}{|c|}{$65-80$} & \multicolumn{2}{|c|}{ Total } \\
\hline & $\begin{array}{l}\text { Cases, } \boldsymbol{n} \\
(\%)\end{array}$ & $\begin{array}{c}\text { Controls, } n \\
(\%)\end{array}$ & $\begin{array}{l}\text { Cases, } n \\
(\%)\end{array}$ & $\begin{array}{c}\text { Controls, } n \\
(\%)\end{array}$ & $\begin{array}{l}\text { Cases, } \mathbf{n} \\
(\%)\end{array}$ & $\begin{array}{c}\text { Controls, } n \\
(\%)\end{array}$ & $\begin{array}{l}\text { Cases, } \mathbf{n} \\
(\%)\end{array}$ & $\begin{array}{c}\text { Controls, } n \\
(\%)\end{array}$ \\
\hline 0 & $20(76.92)$ & $8(61.54)$ & $95(45.45)$ & $12(57.14)$ & $95(28.79)$ & $3(15.00)$ & $210(37.17)$ & $23(42.59)$ \\
\hline$<2$ & $1(3.85)$ & $1(7.69)$ & $32(15.31)$ & $0(0.00)$ & $41(12.42)$ & $1(5.00)$ & $74(13.10)$ & $2(3.70)$ \\
\hline $2-4$ & $4(15.38)$ & $4(30.77)$ & $69(33.01)$ & $5(23.81)$ & 109 (33.03) & $9(45.00)$ & $182(32.21)$ & $18(33.33)$ \\
\hline $5-9$ & $1(3.85)$ & $0(0.00)$ & $10(4.78)$ & $3(14.29)$ & $36(10.91)$ & $1(5.00)$ & $47(8.32)$ & $4(7.41)$ \\
\hline $10-19$ & $0(0.00)$ & $0(0.00)$ & $3(1.44)$ & $1(4.76)$ & $33(10.00)$ & $1(5.00)$ & $36(6.37)$ & $2(3.70)$ \\
\hline$\geqslant 20$ & $0(0.00)$ & $0(0.00)$ & $0(0.00)$ & $0(0.00)$ & $16(4.85)$ & $5(25.00)$ & $16(2.83)$ & $5(9.26)$ \\
\hline Total & $26(100.00)$ & $13(100.00)$ & $209(100.00)$ & $21(100.00)$ & $330(100.00)$ & $20(100.00)$ & $565(100.00)$ & $54(100.00)$ \\
\hline
\end{tabular}




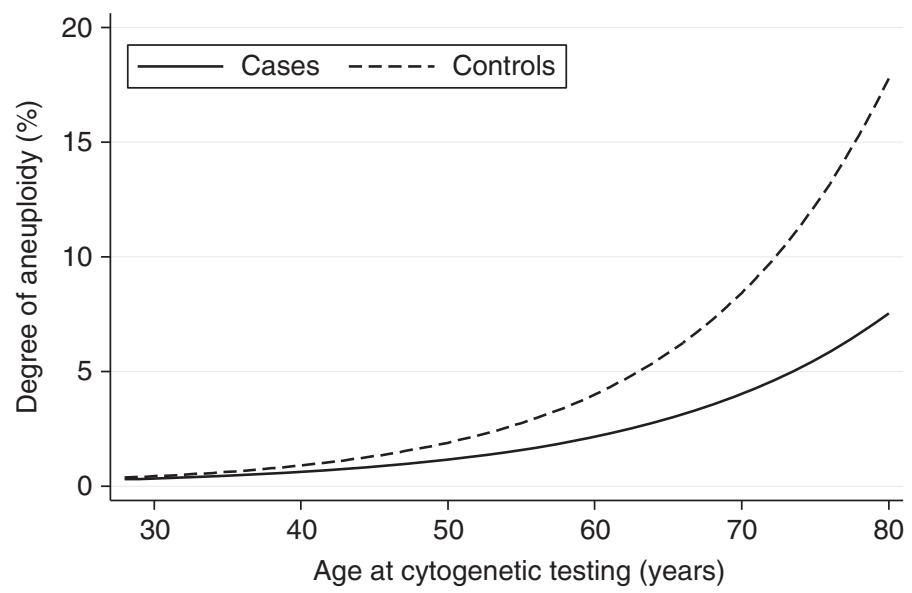

Figure 1. Male breast cancer cases, and controls: degree of aneuploidy by age. Exponential lines fitted to individual aneuploidy values.

\begin{tabular}{|c|c|c|c|c|c|c|}
\hline \multirow[t]{2}{*}{$\begin{array}{l}\text { Sex chromosome } \\
\text { constitution }\end{array}$} & \multicolumn{2}{|c|}{ Cases } & \multicolumn{2}{|c|}{ Controls } & \multicolumn{2}{|c|}{ Total } \\
\hline & $n$ & $\%$ & $n$ & $\%$ & $n$ & $\%$ \\
\hline$X Y$ & 210 & 37.17 & 23 & 42.59 & 233 & 37.64 \\
\hline$X Y / X$ & 330 & 58.41 & 29 & 53.70 & 359 & 58.00 \\
\hline$X Y / X / X X Y$ & 9 & 1.59 & 0 & 0.00 & 9 & 1.45 \\
\hline$X Y / X / X Y Y$ & 12 & 2.12 & 2 & 3.70 & 14 & 2.26 \\
\hline$X Y / X / Y$ & 1 & 0.18 & 0 & 0.00 & 1 & 0.16 \\
\hline$X Y / X X Y$ & 1 & 0.18 & 0 & 0.00 & 1 & 0.16 \\
\hline$X Y / X Y Y$ & 2 & 0.35 & 0 & 0.00 & 2 & 0.32 \\
\hline Total & 565 & 100.00 & 54 & 100.00 & 619 & 100.00 \\
\hline
\end{tabular}

( $P<0.001$ for cases, $P=0.001$ for controls, by analysis of variance). At ages $65-80,71 \%$ of cases and $85 \%$ of controls showed aneuploidy, and $15 \%$ and $30 \%$, respectively, showed $\geqslant 10 \%$ of cells to be aneuploid. Figure 1 shows fitted exponential lines that describe how the degree of aneuploidy varies with age in cases and controls. Both groups show an increase in sex chromosome aneuploidy with age but the proportion of aneuploid cells in the controls is larger than in the cases, and testing the difference between straight lines fitted to the data, after transforming using the arcsine root, found this to be significant $(P=0.03)$. Repetition of the above analyses in subsets of cases according to duration since diagnosis or type of treatment received (chest radiotherapy or chemotherapy, or neither, where this information was available), in subsets of controls by source, or by extent of family history of breast cancer, gave no indication that the distribution of aneuploidy varied between these (data not in Table).

Table 2 shows the sex chromosome constitution of the cells with sex chromosome aneuploidy. As can be seen, the great majority have lost a Y chromosome, whereas a relatively small number have lost and gained a $\mathrm{Y}$, or lost a $\mathrm{Y}$ and gained an $\mathrm{X}$ in a proportion of cells.

\section{DISCUSSION}

Our data showed a highly significant, approximately exponential, increase in sex chromosome aneuploidy in white blood cells with age, both in men from the general population and in men with breast cancer. There was borderline-significant $(P=0.03)$ evidence that the effect was less in the men with breast cancer. To our knowledge, there has been only one previous examination of aneuploidy in non-cultured blood cells in relation to age in the general population and none in people with cancer. Guttenbach et al (1995) studied 138 healthy males and found Y hyperdiploidy to be very low $(0.05 \%)$ up to 15 years but increased to a frequency of $1.34 \%$ in men aged $76-85$ years. Our data showed a larger proportion of cells with sex chromosome aneuploidy especially among the oldest group. The vast majority of these cells were lacking a $\mathrm{Y}$ chromosome. It is thought that age-related sex chromosome aneuploidy may be the result of the sex chromosomes, and especially the inactive X (Abruzzo et al, 1985), being somewhat out of phase with the autosomes in terms of DNA synthesis and participating in the orderly progression of cell division, resulting in anaphase lag and exclusion in micronuclei. A number of studies have shown that micronuclei frequently contain a sex chromosome (Guttenbach et al, 1994). The increasing rates of aneuploidy that we observed with older age could be due to greater somatic mutation rates or accumulation with age, and/or reduced capacity for genomic maintenance, for instance because of attrition of telomeres (Sahin and Depinho, 2010). Sex chromosomes might show a greater ageing effect than autosomes because they are less likely to be selected against - cells with one or two X chromosomes being equally viable, as are cells with one or no Y chromosomes. Although aneuploidy was not a feature specific to familial cases of male breast cancer in our data (and we did not have information on BRCA2 mutation status of our cases), it is notable that in addition to its established role in the repair of DNA damage by homologous recombination, BRCA2 is also thought to be involved in cytokinesis (Mondal et al, 2012). It is possible that disruption of cytokinesis in BRCA2-deficient cells may lead to chromosome aneuploidy.

As the great majority of cells scored on the blood films must have originated in the bone marrow, the aneuploidy seen must be a reflection of that reported in the bone marrow in males. Although a similar loss and gain of the $\mathrm{Y}$ chromosome in cultured $\mathrm{T}$ lymphocytes has been reported in ageing males it is considerably less frequent than that reported here (Jacobs et al, 1963; Galloway and Buckton, 1978). In cultured T lymphocytes of females, aneuploidy of the $\mathrm{X}$ chromosome is observed more frequently than aneuploidy of the $\mathrm{Y}$ chromosome in males. In contrast, there appears to be little or no $\mathrm{X}$ chromosome aneuploidy in bone marrow cells of normal females or of females with a haematological malignancy (Secker Walker, 1971) although Y chromosome loss is very frequent in bone marrow of both normal males and those with a haematological malignancy. However, it is not possible to 
determine whether the age and tissue differences in sex chromosome aneuploidy between males and females is the result of differences in the frequency with which such aneuploidy occurs or results from selective factors operating differently in males and females.

Recent studies have investigated the age distribution of large chromosomal anomalies overall, including aneuploidy plus other anomalies, in autosomes from the general population and from patients with various types of cancer (Laurie et al, 2012; Jacobs et al, 2012). A much smaller increase in prevalence with age was found than in our study, reaching $2-3 \%$ at ages in the 70 s for these anomalies overall, rather than $10-15 \%$ for sex chromosome aneuploidies alone in our data. However, the method used in those studies, based on SNP microarrays, was far less sensitive than the cytogenetic method we used, and was only able to detect abnormal karyotypes if they constituted $>5-10 \%$ of cells. The studies of autosomes found the anomalies more common in cancer patients than in the general population, and especially common in samples taken before haematological malignancy diagnosis (Jacobs et al 2012, Laurie et al, 2012). Our samples from cancer patients were all taken after diagnosis, so there is a possibility that treatment may have affected the degree of aneuploidy, i.e. have purged aneuploid cells preferentially. Examination of risks by type of treatment and duration since treatment did not suggest that this was so, however.

In summary, we have found that sex chromosome aneuploidy is common in uncultured white blood cells from normal men and those with breast cancer, and increases greatly with age. There was a just-significant difference in aneuploidy between breast cancer cases and controls, but there is no obvious explanation for this.

\section{ACKNOWLEDGEMENTS}

We thank the men who participated in the study; Beverley Smith, Deborah Hogben, Robert McCann, Jane Melia, Joanne Micic, Sharon Squires, Margaret Snigorska and Kim Sibley for administrative help and advice; the research nurses Alison Butlin, Margo Pelerin, Jill Wood and Tracy Gardener for collection of blood samples and questionnaire data from participants; Dawn Thomas and her team from the BGS Study for coordinating collection of controls; the cancer registries of England and Wales for providing us with information on eligible participants; and the consultants under whose care the patients were for their advice and help. We are grateful to Michael Jones and Nick Orr for advice. The work was funded by Breakthrough Breast Cancer. The Institute of Cancer Research acknowledges NHS funding to the NIHR Biomedical Research Centre.

\section{CONFLICT OF INTEREST}

The authors declare no conflict of interest.

\section{REFERENCES}

Abruzzo MA, Mayer M, Jacobs PA (1985) Ageing and aneuploidy: evidence for the preferential involvement of the inactive X chromosome. Cytogenet Cell Genet 39: 275-278.

Buckton KE, Jacobs PA, Court Brown WM, Doll R (1962) Cancer subjects and abnormal cell division. Nature 193: 591-591.

Cremer T, Landegent J, Brückner A, Scholl HP, Schardin M, Hager HD, Devilee P, Pearson P, van der Ploeg M (1986) Detection of chromosome aberrations in the human interphase nucleus by visualization of specific target DNAs with radioactive and non-radioactive in situ hybridization techniques: diagnosis of trisomy 18 with probe L1.84. Hum Genet 74: 346-352.

Eastmond DA, Pinkel D (1990) Detection of aneuploidy and aneuploidyinducing agents in human lymphocytes using fluorescence in situ hybridization with chromosome-specific DNA probes. Mut Res 234: 303-318.

Galloway SM, Buckton KE (1978) Aneuploidy and ageing: chromosome studies on a random sample of the population using G-banding. Cytogenet Cell Genet 20: 78-95.

Guttenbach M, Koschorz B, Bernthaler U, Grimm T, Schmid M (1995) Sex chromosome loss and ageing: in situ hybridization studies on human interphase nuclei. Am J Hum Genet 57: 1143-1150.

Guttenbach M, Schakowski R, Schmid M (1994) Aneuploidy and ageing: sex chromosome exclusion into micronuclei. Hum Genet 94: $295-298$.

Jacobs KB, Yeager M, Zhou W, Wacholder S, Wang Z, Rodriguez-Santiago B, Hutchinson A, Deng X, Liu C, Horner MJ, Cullen M, Epstein CG, Burdett L, Dean MC, Chatterjee N, Sampson J, Chung CC, Kovaks J, Gapstur SM, Stevens VL, Teras LT, Gaudet MM, Albanes D, Weinstein SJ, Virtamo J, Taylor PR, Freedman ND, Abnet CC, Goldstein AM, Hu N, Yu K, Yuan JM, Liao L, Ding T, Qiao YL, Gao YT, Koh WP, Xiang YB, Tang ZZ, Fan JH, Aldrich MC, Amos C, Blot WJ, Bock CH, Gillanders EM, Harris CC, Haiman CA, Henderson BE, Kolonel LN, Le Marchand L, McNeill LH, Rybicki BA, Schwartz AG, Signorello LB, Spitz MR, Wiencke JK, Wrensch M, Wu X, Zanetti KA, Ziegler RG, Figueroa JD, Garcia-Closas M, Malats N, Marenne G, Prokunina-Olsson L, Baris D, Schwenn M, Johnson A, Landi MT, Goldin L, Consonni D, Bertazzi PA, Rotunno M, Rajaraman P, Andersson U, Beane Freeman LE, Berg CD, Buring JE, Butler MA, Carreon T, Feychting M, Ahlbom A, Gaziano JM, Giles GG, Hallmans G, Hankinson SE, Hartge P, Henriksson R, Inskip PD, Johansen C, Landgren A, McKean-Cowdin R, Michaud DS, Melin BS, Peters U, Ruder AM, Sesso HD, Severi G, Shu XO, Visvanathan K, White E, Wolk A, Zeleniuch-Jacquotte A, Zheng W, Silverman DT, Kogevinas M, Gonzalez JR, Villa O, Li D, Duell EJ, Risch HA, Olson SH, Kooperberg C, Wolpin BM, Jiao L, Hassan M, Wheeler W, Arslan AA, Bueno-de-Mesquita HB, Fuchs CS, Gallinger S, Gross MD, Holly EA, Klein AP, LaCroix A, Mandelson MT, Petersen G, Boutron-Ruault MC, Bracci PM, Canzian F, Chang K, Cotterchio M, Giovannucci EL, Goggins M, Hoffman Bolton JA, Jenab M, Khaw KT, Krogh V, Kurtz RC, McWilliams RR, Mendelsohn JB, Rabe KG, Riboli E, Tjønneland A, Tobias GS, Trichopoulos D, Elena JW, Yu H, Amundadottir L, Stolzenberg-Solomon RZ, Kraft P, Schumacher F, Stram D, Savage SA, Mirabello L, Andrulis IL, Wunder JS, Patiño García A, Sierrasesúmaga L, Barkauskas DA, Gorlick RG, Purdue M, Chow WH, Moore LE, Schwartz KL, Davis FG, Hsing AW, Berndt SI, Black A, Wentzensen N, Brinton LA, Lissowska J, Peplonska B, McGlynn KA, Cook MB, Graubard BI, Kratz CP, Greene MH, Erickson RL, Hunter DJ, Thomas G, Hoover RN, Real FX, Fraumeni Jr JF, Caporaso NE, Tucker M, Rothman N, Pérez-Jurado LA, Chanock SJ (2012) Detectable clonal mosaicism and its relationship to aging and cancer. Nat Genet 44: 651-658.

Jacobs PA, Court Brown WM, Doll R (1961) Distribution of human chromosome counts in relation to age. Nature 191: 1178-1180.

Jacobs PA, Brunton M, Court Brown WM, Doll R, Goldstein H (1963) Change of human chromosome count distribution with age: evidence for a sex difference. Nature 197: 1080-1081.

Laurie CC, Laurie CA, Rice K, Doheny KF, Zelnick LR, McHugh CP, Ling H, Hetrick KN, Pugh EW, Amos C, Wei Q, Wang LE, Lee JE, Barnes KC, Hansel NN, Mathias R, Daley D, Beaty TH, Scott AF, Ruczinski I, Scharpf RB, Bierut LJ, Hartz SM, Landi MT, Freedman ND, Goldin LR, Ginsburg D, Li J, Desch KC, Strom SS, Blot WJ, Signorello LB, Ingles SA, Chanock SJ, Berndt SI, Le Marchand L, Henderson BE, Monroe KR, Heit JA, de Andrade M, Armasu SM, Regnier C, Lowe WL, Hayes MG, Marazita ML, Feingold E, Murray JC, Melbye M, Feenstra B, Kang JH, Wiggs JL, Jarvik GP, McDavid AN, Seshan VE, Mirel DB, Crenshaw A, Sharopova N, Wise A, Shen J, Crosslin DR, Levine DM, Zheng X, Udren JI, Bennett S, Nelson SC, Gogarten SM, Conomos MP, Heagerty P, Manolio T, Pasquale LR, Haiman CA, Caporaso N, Weir BS (2012) Detectable clonal mosaicism from birth to old age and its relationship to cancer Nat Genet 44: 642-650.

Mondal G, Rowley M, Guidugli L, Wu J, Pankratz VS, Couch FJ (2012) BRCA2 localization to the midbody by filamin A regulates cep55 signaling and completion of cytokinesis. Dev Cell 23: 137-152. 
O’Riordan ML, Berry EW, Tough IM (1970) Chromosome studies on bone marrow from a male control population. Br J Haemat 19: 83-90.

Sahin E, Depinho RA (2010) Linking functional decline of telomeres, mitochondria and stem cells during ageing. Nature 464: 520-528.

Secker Walker LM (1971) The chromosomes of bone-marrow cells of haematologically normal men and women. Br J Haemat 21: 455-461.

Swerdlow AJ, Schoemaker MJ, Higgins CD, Wright AF, Jacobs PA. on behalf of the UK Clinical Cytogenetics Group (2005) Cancer incidence and mortality in men with Klinefelter syndrome: a cohort study. J Natl Cancer Inst 97: 1204-1210.

Swerdlow AJ, Jones ME, Schoemaker MJ, Hemming J, Thomas D, Williamson J, Ashworth A (2011) The Breakthrough Generations Study: design of a long-term UK cohort study to investigate breast cancer aetiology. $\mathrm{Br} J$ Cancer 105: 911-917.

United Kingdom Cancer Cytogenetics Group (UKCCG) (1992) Loss of the Y chromosome from normal and neoplastic bone marrows. Gene Chromosome Cancer 5: 83-88.

This work is published under the standard license to publish agreement. After 12 months the work will become freely available and the license terms will switch to a Creative Commons AttributionNonCommercial-Share Alike 3.0 Unported License. 